\title{
Effect of Entrepreneurship Education and Self Efficacy Towards The Intention of Entrepreneurship
}

\author{
Patricia Martyajuarlinda', Djoko Dwi Kusumajanto² \\ Department of Management, Universitas Negeri Malang \\ E-mail: Atriciaamartyaa@gmail.com
}

\begin{abstract}
This study aims to know the influence of entrepreneurship education and self efficacy toward student's intention of entrepreneurial. The population in this study was 140 students of grade XII marketing and accounting for Islamic Vocational High School with a sample of 104 students. The method of data collection in this study used questionnaires and documentation. This research is a quantitative study, using descriptive analysis, multiple linear regression analysis, and classic assumption tests which include normality, multicollinearity, and heteroscedasticity tests. Based on the result, entrepreneurship education and self efficacy show a significant influence on student's intention of entrepreneurial at SMK Islam Batu.
\end{abstract}

Keywords: entrepreneurship education, self efficacy, entrepreneurial intention

\section{INTRODUCTION}

Recorded in BPS in February 2017, the unemployment rate in Indonesia reached 7.01 million people. Vocational high school graduates contributed the highest number of unemployed people in Indonesia at 9.27 percent. According to the National Education System Law No. 20 of 2003 vocational education is secondary education that prepares students primarily to work according to certain fields. For this reason, efforts to solve the unemployment problem must at least have a change in the mindset of the community, especially graduates of vocational students from looking for work to create their own jobs. Opinions from Saroni (2012) for now and in the future we are required to be more creative in facing this life, we can create a variety of jobs so as to reduce unemployment in the community by providing entrepreneurial competence to students. Kasmir (2011) entrepreneurship is a soulless person who dares to take risks to open a business on various occasions. In addition to being done to reduce unemployment, entrepreneurs can contribute to the Indonesian economy through taxes generated from entrepreneurship.

One of the supporting factors of entrepreneurship is the existence of these desires and desires by Wijaya (2007) referred to as intentions which are components in individuals who refer to the desire to do certain behaviors. Intention in the English dictionary means willingness. Intention is the most important part of an individual driven by someone's motivation to act. The statement above is supported by the opinion of Suryana (2013) that willingness is determined or strong intention and high motivation. Intention is needed as a first step in starting entrepreneurship. The intention of entrepreneurship can be said as a desire that exists in a person to carry out an entrepreneurial act (Wijaya, 2007). In fact, many alumni of vocational high schools are not ready to implement their knowledge as entrepreneurs and become unemployed because they prefer to work in companies. This is supported by the results of a study by Hartini (2002) which states that up to now, among SMK graduates, there are not many who are oriented and intend to work alone or entrepreneurship with the knowledge gained. Based on Theory of Planned Behavior (Ajzen, 1988) the intention of 
entrepreneurship is determined by several factors, namely attitudes, subjective norms, and perceived behavioral control.

The intention of students to entrepreneurship is influenced by several factors, one of which is entrepreneurship education taught in schools. Entrepreneurship education is in the form of knowledge and understanding of values, behavior and abilities regarding entrepreneurship in facing life challenges (Anggraeni \& Nurcaya, 2016). Entrepreneurship education provided in schools, not only provides a theoretical foundation for the concept of entrepreneurship but shapes attitudes, behaviors, and mindset (entrepreneur). To encourage students' intention to become entrepreneurs not only from school, but also from the surrounding environment, both the family environment and the community. As in the city of Batu as a place of research by researchers who incidentally as a city of tourism with many tourist attractions and Batu Islam Vocational School is a strategic school to improve entrepreneurship education. This is actually an opportunity for students of Batu Islamic Vocational School, because they can take advantage of this opportunity to learn and seek experience for entrepreneurship.

Wedayanti \& Giantari's (2016) research with the title The Role of Entrepreneurship Education in Mediating the Effect of Subjective Norms on Entrepreneurial Intentions shows that there is a partial positive and significant influence between entrepreneurship education variables on entrepreneurial intentions, which means entrepreneurship education can play a role in developing entrepreneurial intentions.

In addition to entrepreneurship education as an external factor, there are also internal factors to develop entrepreneurial intentions, namely the need for motivation and self-confidence called self efficacy. Self-efficacy is a person's belief in his ability to complete a job (Setiawan, 2014). Self efficacy can also be interpreted as a form of individual belief in believing in their own abilities in carrying out an action. That selfefficacy consists of several dimensions, namely: Magnitude (level of difficulty), Strength, Generality . Opening a business requires confidence in one's own ability that his business will succeed. Self-confidence alone will foster one's entrepreneurial intentions. If someone is not sure of their abilities, it is unlikely that the person will have the intention of entrepreneurship.

In the research of Adnyana \& Purnami (2016) with the title The Influence of Entrepreneurship Education, Self-Efficacy, and Locus of Control. In the Intention of Entrepreneurship shows Self efficacy has a positive and significant effect on the intention of entrepreneurship of undergraduate students of the Faculty of Economics and Business, Udayana University, which means that the higher the self-efficacy students have, the higher the student's intention to become entrepreneurs.

This research was conducted at Batu Islamic Vocational School. For the selection of Grade XII students because they have taken entrepreneurship subjects, they will soon graduate and be ready to enter the workforce. Based on this description, this study aims to examine the Influence of Entrepreneurship Education and Self-Efficacy on Entrepreneurial Intention (Study in Grade XII Students of the Department of Marketing and Accounting at the Batu Islamic Vocational School).

This study aims to determine: (1) description of entrepreneurship education variables and self-efficacy and entrepreneurial intentions (2) there is an influence of entrepreneurial education partially on entrepreneurial intentions (3) the effect of partial self-efficacy on students' entrepreneurial intentions (4) the influence of 
entrepreneurship education and simultaneous self-efficacy towards entrepreneurship intentions.

\section{METHOD}

This research is a quantitative study, using descriptive analysis, multiple linear regression analysis, and classic assumption tests which include normality, multicollinearity, and heteroscedasticity tests. The population in this study was 140 students of grade XII marketing and accounting for Islamic Vocational High School with a sample of 104 students. Sampling uses Probability sampling technique. The method of data collection in this study used questionnaires and documentation. The questionnaire method is used for primary data collection, namely entrepreneurship education, selfefficacy and the intention of entrepreneurship. The documentation method is used for secondary data retrieval, namely the list of names of grade XII students and profiles of Islamic Vocational Schools.

\section{RESULTS \& DISCUSSION Result}

From the results of the analysis it is known that the characteristics of respondents are based on marketing majors (34.62 percent), and accounting (65.38 percent). Characteristics of respondents based on sex, male (11.52 percent) and women (88.46 percent). Based on the results of descriptive statistical analysis, it is known that entrepreneurship education in grade XII of Batu Islamic Vocational High School obtained a grand mean of 4.12 this indicates that the condition of entrepreneurship education is in the good category. Self-efficacy of grade XII of Islamic Vocational High School obtained grand means of 4.17 which indicates that students' self-efficacy conditions are in a good category. The entrepreneurial intention of class XII students of Islamic Rock Vocational High School obtained grand means of 4.22 this indicates that the condition of students' entrepreneurial intentions in the category is very good. The results of multiple regression analysis can be seen in the Table 1.

Table 1. Multiple Linear Regression Test Results

\begin{tabular}{|c|c|c|c|c|c|c|}
\hline & \multirow{2}{*}{ Model } & \multicolumn{2}{|c|}{ Unstandardized Coefficients } & \multirow{2}{*}{$\begin{array}{c}\begin{array}{c}\text { Standardized } \\
\text { Coefficients }\end{array} \\
\text { Beta } \\
\end{array}$} & \multirow[t]{2}{*}{$\mathbf{T}$} & \multirow{2}{*}{ Sig. } \\
\hline & & $\mathbf{B}$ & Std. Error & & & \\
\hline \multirow[t]{3}{*}{1} & (Constant) & 5.815 & 4.244 & & 1.370 & .174 \\
\hline & $\begin{array}{l}\text { Entrepreneurship } \\
\text { Education }\end{array}$ & .474 & .104 & .450 & 4.560 & .000 \\
\hline & Self-Efficacy & .256 & .114 & .222 & 2.246 & .027 \\
\hline
\end{tabular}

Variables = Intention of Entrepreneurship

b. $\mathrm{t}$ table $=1,983$

c. F table $=2.302$

d. $F$ count $=29,981$

The results of hypothesis testing: (1) entrepreneurial education partially have a positive and significant effect on Entrepreneurial Intentions (2) partial self-efficacy has a 
positive and significant effect on Entrepreneurial Intentions (3) there is a significant positive influence between entrepreneurship education and simultaneous self-efficacy of Intentions Entrepreneurship. The results of this study indicate that the entrepreneurship education variables possessed by students of grade XII Marketing and Accounting are classified as good with the acquisition of an average value of 4.12.

\section{Discussion}

In terms of entrepreneurship education in the family environment, parents communicate actively to their children to provide opportunities for their children to achieve when they are entrepreneurs. Regarding entrepreneurship education in the school environment the facilities and infrastructure possessed by the Batu Islamic Vocational School have supported students in the practice of entrepreneurship and teachers who continue to motivate them to study hard and become successful people in the future. Besides the family environment and the school environment, entrepreneurship education can also be obtained in the community. By looking at the surrounding environment, we can also obtain knowledge and experience about entrepreneurship. In addition to studying the experience of people around who have run a business, it can also be done by participating in organizational activities in the community such as opening a business with youth organizations.

Based on the results of the research that has been done, it is known that entrepreneurship education has a significant positive effect on the intention of entrepreneurship of class XII students in the marketing and accounting department of the Islamic Islamic Vocational School. It means that the more often you get entrepreneurship education, the more your entrepreneurial intention will be. Entrepreneurship education lasts a lifetime where and at any time. Entrepreneurship education is not only learned at school, but also can be learned from the environment around us, both the family environment and the community.

Entrepreneurship education is the process of instilling entrepreneurial spirit to mature oneself so that the person is able to live independently, creatively, and innovatively with increasing knowledge. With the existence of entrepreneurship education, it will further increase the knowledge and real experience for entrepreneurship for students and make them more trained then the confidence will emerge to start a business. entrepreneurship education is an important factor in growing and developing desire, soul, and entrepreneurial behavior among the younger generation because education is the source of overall attitudes and intentions to become successful entrepreneurs in the future (Welsh et al., 2016).

There is a significant effect of entrepreneurship education on entrepreneurial intentions (Küttim et al., 2014). The results of his research stated that students who received entrepreneurship education tended to have better entrepreneurial intentions than students who did not get entrepreneurship education.

The results of this study indicate that the variables of self-efficacy possessed by class XII students of Marketing and Accounting are classified as good with the acquisition of an average value of 4.17. Self-efficacy is a person's belief in their abilities or competencies for the performance of a given task, achieving goals, or overcoming an obstacle (Setiawan, 2014). Most students are able to overcome the problems that arise in starting a business, students feel confident that by working hard will get the desired results, students feel able to complete the task well, and students always try to get maximum results. Students can strengthen their self-efficacy by adding knowledge about 
entrepreneurship from various sources both from books, newspapers, and the internet and the experiences of others around them.

Based on the results of the research that has been conducted, it is known that self-efficacy has a significant positive effect on the intention of entrepreneurship of grade XII students in the marketing and accounting department of the Islamic Islamic Vocational School. It means that the higher the confidence students have, the higher their entrepreneurial intentions. Likewise also vice versa the lower his confidence, then the intention of entrepreneurship will also be low.

The higher the student's confidence and mental maturity, the higher their role is to arouse the intention of student entrepreneurship. Self-confidence is needed, without any self-confidence, a person will tend to avoid a job or situation because of distrust of his abilities and feel he is unable to do so. As in entrepreneurship, we also need confidence in our abilities, as well as when we are starting to open a capital business that is needed not only money but feeling confident to take action to open the business, the more confident our abilities are, the stronger one's intentions for entrepreneurship.

With the existence of self-efficacy, a person will be more confident in his ability, that belief that can encourage someone to dare to take an action or behavior carried out with confidence. Self-efficacy also makes students confident in taking risks and competing. So that students will be more courageous in doing or running a business of their own. Self efficacy influences a person's belief in whether or not goals have been targeted, with the higher a person's self-confidence in his ability to try, the greater his desire to become an entrepreneur (Setiawan, 2014). The results of this study are also supported by previous research, namely research conducted by Vemmy (2012) states that self-efficacy is proven to affect student intentions and self-efficacy is the most dominant variable that influences entrepreneurial intention in students.

\section{CONCLUSION}

The findings in this study conclude that partially and simultaneously the variables of entrepreneurship education and self-efficacy have a positive and significant effect on entrepreneurial intentions. For students more open to the surrounding environment, especially with (individuals or organizations) who have been involved in entrepreneurship activities and students can also take advantage of their day off to learn entrepreneurship considering the city of rock as a tourist destination. For teachers it is recommended to continue to give encouragement, motivation and insight about problems that may be faced by students in entrepreneurship. For school principals it is recommended to maximize the facilities and infrastructure as a practical laboratory. In this way a balanced atmosphere of theory and practice will be created and include students in entrepreneurship seminars held by schools to increase knowledge and knowledge about the business world.

\section{REFERENCES}

Adnyana, I., \& Purnami, N. 2016. Effect of Entrepreneurship Education, Self Efficacy and Locus of Control on Entrepreneurial Intention. E-Jurnal Manajemen Unud, 5(2), 1160-1188.

Ajzen, I. 1988. Attitude, Personality, and Behavior. Milton Keynes: Open University Press. 
Anggraeni, D. A., \& Nurcaya, I. 2016. The role of self-efficacy in mediating the influence of entrepreneurship education on entrepreneurial intentions. E-Jurnal Manajemen Unud, 5, (4), 2424-2453

Bukirom, I. H., Permana, A., \& Martono. 2014. The Effect of Entrepreneurship Education and Entrepreneurial Motivation on the Establishment of Student Entrepreneurial Souls. Media Economics and Management, 29(2), 144-151.

Hartini, A., 2002. Analysis of the Relationship Between Employee Commitment, Climate Organization and Performance of Employee Work, Case Study of Corporate \& Unit Division of Network PT Telkom Indonesia, Tbk. JREM, 25 - 33.

Kasmir. 2011. Bank and other Financial Institutions. Editions of Revision 11. Jakarta: Rajawali Pers.

Küttim, M., Kallaste, M., Venesaar, U., Kiis, A., 2014. Entrepreneurship Education at University Level and Students' Entrepreneurial Intentions. Procedia - Social and Behavioral Sciences, The 2nd International Scientific conference, Contemporary Issues in Business, Management and Education 2013. 110, 658-668. https://doi.org/10.1016/j.sbspro.2013.12.910

Saroni, M. 2012. Managing Journal of School Education. Jogjakarta: ArRuzz Media. (Indonesian Origin)

Setiawan, J.L. 2014. Examining Entrepreneurial Self-efficacy among Students. Procedia Social and Behavioral Sciences, The 5th Indonesia International Conference on Innovation, Entrepreneurship, and Small Business (IICIES 2013) 115, 235-242. https://doi.org/10.1016/j.sbspro.2014.02.431

Suryana. 2013. Entrepreneurship Tips and Process Towards Success. Jakarta: Salemba Empat.

Vemmy, C. 2012. Factors that influence the entrepreneurial intentions of SMK students. Jurnal Pendidikan Vokasi, 2(1), 117-125. https://doi.org/10.21831/jpv.v2i1.1022.

Welsh, D.H.B., Tullar, W.L., Nemati, H., 2016. Entrepreneurship education: Process, method, or both? Journal of Innovation \& Knowledge 1, 125-132. https://doi.org/10.1016/j.jik.2016.01.005

Wedayanti, N.P \& Giantari, I.G. 2016. Peran Pendidikan Kewirausahaan Dalam Memediasi Pengaruh Norma Subyektif Terhadap Niat Berwirausaha. E-Jurnal Manajemen Unud, 5(1), 533 - 560.

Wijaya, T. 2007. Relationship between Adversity Intelligence and Entrepreneurial Intention (Empirical Study in Yogyakarta 7 Vocational High School Students). Jurnal Manajemen Dan Kewirausahaan, 9(2), 117-127 